\title{
Bør ledere være veiledere for nyutdannede lærere? En problematisering basert på teori om profesjonalitet og etisk bevissthet
}

\author{
Eli Lejonberg ${ }^{1 *}$ \\ ${ }^{1}$ Universitetet i Oslo
}

\section{Sammendrag}

\begin{abstract}
Mange nyutdannede lærere i norsk skole har i dag lederen sin som veileder. At veilederansvar for nyutdannede lærere legges til lederrollen er blitt problematisert tidligere. Men hvorfor kan det være et problem at ledere er veiledere for nyutdannede? Er det fordi de mangler relevant kompetanse, eller er det andre forhold som gjør det problematisk å kombinere lederansvar med å være veileder for en nyutdannet lærer? I denne artikkelen belyses utfordringer knyttet til det å bruke nyutdannedes leder til veileder. Blant annet diskuteres hva profesjonalitet i veiledningsforhold i skolen innebærer. Spesielt fokuseres det på betydningen av etisk bevissthet for veiledere. Basert på teori om veilederes etiske forpliktelser overfor veisøkere problematiseres det å legge veilederansvar til ledere. Asymmetrien mellom ledere og veisøkere, og lederes makt og forpliktelser til andre aktører utenfor veiledningsforholdet kompliserer veiledningsforholdet. Det argumenteres for at nyutdannede har behov for veiledere som ikke også er ledere.
\end{abstract}

Nøkkelord: veiledning; etikk i veiledning; nyutdannede lærere; ledere som veiledere; lærerprofesjonalitet; mentoring

\author{
* Kontakt: \\ Eli Lejonberg \\ Institutt for lærerutdanning og skoleforskning \\ Det utdanningsvitenskapelige fakultet \\ Universitetet i Oslo \\ E-post: eli.lejonberg@ils.uio.no
}

\section{Veiledningsoppdraget og ledere som veiledere}

Utgangpunktet for å etablere veiledningsforhold for nyutdannede i skolen er å bidra til at veisøker utvikler seg til å bli en (enda) bedre lærer. Det er imidlertid dokumentert at så ikke nødvendigvis er utfallet. Flere studier har belyst hvordan veiledningens fokus og form er av betydning for om veiledningen bidrar positivt overfor veisøker (Hobson \& Malderez, 2013; Hobson \& McIntyre, 2013; Hobson, Ashby, Malderez \& Tomlinson, 2009; Harrison, Dymoke \& Pell, 2006; Long, 1997). Dermed er det relevant å undersøke 
Bør ledere være veiledere for nyutdannede lærere? En problematisering basert på teori om profesjonalitet og etisk bevissthet

hvordan ulike aspekter ved veiledningsforhold kan være av betydning for den veiledningen nyutdannede får. Videre er dette spesielt interessant å utforske i norsk kontekst i dag ettersom det nylig er blitt vedtatt i Stortinget at det skal utvikles nasjonale rammer for å sikre alle nyutdannede lærere veiledning (Utdanningsdirektoratet, 2018). Når vi vet at bare $61 \%$ av de nyutdannede ble omfattet av en veiledningsordning i 2016 (Rambøll, 2016), er det nærliggende å spørre seg hvem som skal veilede alle de nyutdannede lærerne i tiden fremover. Ettersom flere nyutdannede lærere i Norge i dag veiledes av sine ledere $^{1}$, er det, i lys av utvidelsen av veiledningsordningen, spesielt interessant å belyse potensielle utfordringer relatert til å kombinere veilederrollen med lederrollen.

Det er ulike holdninger nasjonalt knyttet til å overlate veiledningsansvaret til ledere. Det er motstand mot slike ordninger fra flere hold, samtidig som det er vanlig praksis i andre sammenhenger. Eksempelvis skriver Oslo kommune på sine hjemmesider at «veilederen kan være en erfaren lærer eller leder som $\emptyset$ nsker å bidra til å løfte de nyutdannede» (Utdanningsetaten, 2018). Utdanningsetaten i Oslo ser altså ut til å vektlegge erfaring fremfor veilederutdanning, samt at de trekker frem ledere som relevante kandidater til veilederrollen. Det var også den opprinnelige praksisen i Oslo å legge veiledningsansvaret for de nyutdannede til ledere etter at intensjonsavtalen mellom KS og KD i 2010 trakk frem at alle nyutdannede burde få en veileder. Som en motsetning til sitatet over, skriver det nasjonale nettverket for veiledning av nyutdannede lærere på sine nettsider at «det anbefales ikke å oppnevne nyutdannedes leder» som veileder (Nettverket, 2018a). Det tydeliggjøres imidlertid ikke hvorfor eller på hvilket grunnlag denne anbefalingen gjøres. Utdanningsdirektoratet skriver på sine nettsider at «veiledere bør være erfarne lærere med tilleggsutdanning i veiledning», og tar således ikke stilling til om det skal vurderes fordeler eller ulemper knyttet til om veileder også er leder (Utdanningsdirektoratet, 2017). Målet med denne artikkelen er å belyse utfordringer knyttet til det å utnevne nyutdannedes leder til veileder. Jeg vil ta utgangspunkt i teori om profesjonalitet og etisk bevissthet i veiledning for å synliggjøre relevante aspekter ved veiledningsforhold i norsk skole i dag. Rambøll $(2014,2015,2016)$ har evaluert veiledningsordningen for nyutdannede, og finner stor variasjon i hvordan ordningene utformes i Norge. Mange av de nyutdannede som får veiledning, veiledes av ledere (Rambøll, 2014, 2016). Det varierer også om den som er oppnevnt som veileder, har relevant skolering (Rambøll, 2014).

I denne artikkelen forstås et veiledningsforhold som en relasjon hvor veileder og veisøker inngår, og som har profesjonell utvikling for veisøker som mål. Veilederens oppgave i forholdet er å bidra til veisøkers profesjonelle utvikling (Lejonberg, 2016). Hvem som er veileder og hvem som er veisøker, har gjerne sammenheng med erfaring og status. Den som er veileder har eksempelvis ofte lengre erfaring enn veisøker og kan også ha formell kompetanse, eksempelvis fra en veilederutdanning.

Ledere, med rektor som øverste ansvarlig, har personalansvar for alle lærerne ved en skole. Dette innebærer blant annet ansvar for at «alle ansatte får veiledning og støtte i sitt arbeid» (Utdanningsdirektoratet, 2015, s. 6). Et slikt mandat er sentralt i læringssentrert ledelse, en tilnærming hvor "veiledning og evaluering» av lærerarbeidet inngår (Brandmo \& Aas, 2017, s. 55). Denne tilnærmingen står sterkt i norsk skole, og ledere veileder eksempelvis i medarbeidersamtaler og i oppfølgingssamtaler i forbindelse med klasseromsobservasjon eller undervisningsvurdering (Brandmo \& Aas, 2017; Lejonberg, Elstad \& Christophersen, 2017). Dermed veileder ledere gjerne også nyutdannede. $\AA$ ha det formelle veilederansvaret for en nyutdannet i forbindelse med veiledningsordningen for nyutdannede lærere er imidlertid en annen oppgave, som strekker seg utover den generelle oppfølgingen ledere skal ut $\varnothing$ ve overfor sine ansatte. Denne veiledningsordningen innebærer at det oppnevnes en egen veileder ved skolen som skal følge opp den nyutdannedes første tid som lærer. Denne personen kalles gjerne veileder eller mentor (Smith, 2018). Intensjonen er å bidra til at den nyutdannede får en god overgang til læreryrket, og til at han/hun blir trygg i lærerrollen (Utdanningsdirektoratet, 2017).

\footnotetext{
${ }^{1}$ Av dem som får veiledning finner Rambøll (2016) at $58 \%$ veiledes av kollega, $33 \%$ av rektor og $9 \%$ av begge. Hvor mange av de $58 \%$ som veiledes av en kollega som veiledes av en kollega som også er leder (eksempelvis avdelingsleder) er uvisst.
} 


\section{Hvilke veiledningsbehov har nyutdannede lærere?}

Begrepet praksissjokk er blitt brukt for å beskrive nyutdannede læreres møte med lærerjobben (Caspersen \& Raaen, 2014). Andre har brukt metaforer som å holde hodet over vannet, bli kastet ut på dypt vann eller å drukne om begynnende læreres opplevelse av møtet med lærerhverdagen (Smith, Ulvik \& Helleve, 2013; Stålsett, 2006; Varah, Theune \& Parker, 1986; Lortie, 1975). Selv om det er blitt argumentert for at ideen om praksissjokk er overdrevet og svakt empirisk forankret (Arnesen \& Aamodt, 2010), finner Rambøll (2016, s.16) i sin evaluering at «74 prosent av veilederne og 59 prosent av veisøkerne i barnehage og skole er enige i at overgangen fra utdanningen er så krevende at det kan kalles et sjokk». Det er altså krevende for de nyutdannede å skulle omstille seg fra å være student til å være lærer. Videre er det en utfordring at de ikke kjenner sine kollegaer på skolen de skal jobbe på, og at skolen ofte ikke har de nødvendige støttestrukturene på plass. Det kan også være vanskelig for nyutdannede å sette ord på de utfordringer og behov de har (Caspersen \& Raaen, 2014).

Hobson og McIntyre (2013) beskriver at nye lærere er strategiske og forsiktige når det kommer til å sette ord på utfordringer de opplever. De peker på at ordninger hvor veileder skal vurdere eller kan ha innvirkning på veisøkers videre ansettelse og anseelse i kollegiet, kan fremme strategier hvor veisøker heller vil etterstrebe å fremstå som dyktig enn å sette ord på de utfordringer de opplever. Dette er også relevant i norsk kontekst blant annet ettersom nyutdannede ofte er i midlertidige stillinger (Bjørndal, 2016; Lejonberg, 2014). Dahl og Scheie (i prosess) viser hvordan det å få fast jobb kan bidra til at nyutdannede opplever det som lettere å være ærlig om utfordringer de har, relatert til lærerrollen.

Alle veisøkere er naturligvis ulike med individuelle behov, men likevel er det mulig å peke på noen behov som nyutdannede generelt gjerne har, og som skiller dem fra andre grupper veisøkere. Smith (2015) peker på at det er noe grunnleggende lærere trenger å kunne, og som karakteriserer nyutdannedes behov i veiledning. Dette grunnleggende, som fordrer veiledning, omfatter sider ved faglige kjernekunnskaper, elementære undervisningsferdigheter og generelle kunnskaper om læreryrket. Hvis så er tilfellet, kunne man jo tenke seg at enhver lærer eller leder kan veilede nyutdannede basert på de kunnskaper og erfaringer disse har. Men forskning indikerer altså at det ikke er så enkelt (se eksempelvis Lejonberg, 2016; Hobson \& Malderez, 2013; Hobson et al., 2009). I det neste avsnittet, om profesjonalitet i veiledning, vil dette bli nærmere belyst.

\section{Hva er profesjonalitet i veiledning?}

I følge nynorskordboka, forklares profesjonalitet som det å være dugande som fagmenneske. Dette er en forklaring som kan sies å være relevant for å forstå bruk av begrepet profesjonalitet i dagligtale. Profesjonalitet kan imidlertid forstås som et vagt begrep hvor det alltid vil være uklarheter forbundet med hva som faller innenfor og utenfor begrepet (Wittek \& Kvernbekk, 2011; Sorensen, 2006; Varzi, 2001). Det er et begrep på høyt abstraksjonsnivå, noe som innebærer at det favner bredt og åpner for unntak (Troye, 1994). Mausethagen og Granlund (2012) har vist hvordan ulike aktører knytter svært ulikt innhold til begrepet lærerprofesjonalitet. Lejonberg og Elstad (2014) beskriver hvordan aktører som KS og Utdanningsforbundet bruker begrepet strategisk i kamp om utdanningspolitikkens innhold. Mens KS knytter det å være profesjonell til bruk av effektive metoder lærere kan tilegne seg hvis de samarbeider på skolen, knytter Utdanningsforbundet begrepet til utøvelse av skjønn og lærers autonomi. De positive assosiasjonene til begrepet, som også fremkommer så tydelig i nynorskordbokens forklaring, gjør dessuten profesjonalitet til et begrep det er attraktivt for dem med en politisk agenda å fylle med det innholdet som passer dem. Siden profesjonalitetsbegrepet både er vagt og uklart, blir det følgelig en utfordring å avklare hva som ligger i profesjonalitet i veiledning, fordi veiledningsbegrepet heller ikke er entydig. Likevel er profesjonalitet et nyttig begrep som kan fungere bevisstgjørende i diskusjoner om hva god veiledning kan være og ikke minst: hvordan kan man legge til rette for strukturer som kan fremme kvalitet i veiledning. Derfor vil jeg i det følgende presentere teori om hva profesjonalitet i veiledning kan innebære. Jeg vil begynne med å gå noe mer inn på hvordan begrepet lærerprofesjonalitet kan forstås. 
Bør ledere være veiledere for nyutdannede lærere? En problematisering basert på teori om profesjonalitet og etisk bevissthet

Evans (2008) forstår lærerprofesjonalitet som et ideologisk, holdnings-, intellektuelt og epistemologisk basert ståsted hos individet i relasjon til utøvelse av læreryrket, og som influerer lærerens profesjonelle praksis. Hun presenterer altså lærerprofesjonalitet som et komplekst begrep som omhandler hva man som lærer står for, og som influerer ens praksis. At profesjonalitet er knyttet til utøvelse i yrket, understrekes også av Svensson (2006) som påpeker at profesjonalitet gjerne kalles for kontekstuell kompetanse. At veiledere innehar profesjonskompetanse kan dermed forstås som en forutsetning for at et veiledningsforhold skal preges av profesjonalitet. For å belyse nærmere hva profesjonalitet i veiledning innebærer, trekker jeg inn kilder som mer konkret beskriver veileders profesjonskompetanse. Illeris (2011) skriver at profesjonskompetanse kan forstås som et helhetlig konsept som integrerer alt det er nødvendig å håndtere i forbindelse med yrkesutøvelsen.

\section{Veilederes profesjonskompetanse}

Det er skrevet lite om veilederes profesjonskompetanse både nasjonalt og internasjonalt. I et bidrag bruker Smith (2016) begrepet profesjonskunnskap når hun argumenterer for hva det er veiledere trenger å kunne. Hun trekker frem at veiledere må kunne artikulere egen praksisteori, kunne gi gode tilbakemeldinger, kunne bygge bro mellom teori og praksis, kunne modellere god undervisning, kunne bidra til systematisk refleksjon og at de må ha kunnskap om praksisorientert forskning, om læringsfellesskap og praksisfellesskap og om skolens struktur og ulike roller. Imidlertid er det ikke gitt at profesjonskompetanse er det samme som kunnskaper man trenger for å ut $\varnothing$ ve en rolle. Hatlevik (2014) peker på at begrepene profesjonskunnskap og profesjonskompetanse brukes overlappende i forskningslitteratur. Hun argumenterer imidlertid for at begrepet profesjonskompetanse er å foretrekke ettersom dette begrepet tydeliggjør et fokus som strekker seg utover teoretisk kunnskap.

Ettersom veileders profesjonskompetanse er lite beskrevet, vil jeg presentere noen forslag som kan være relevante for å belyse hva veilederes profesjonskompetanse består i. Forslagene tar utgangspunkt i bidrag som beskriver hva læreres profesjonskompetanse innebærer. Det følgende kan altså forstås som et argument for at veiledere for nyutdannede lærere trenger den kompetanse lærere trenger, i tillegg til veilederkompetanse. Dette fordi veiledere for nyutdannede lærere skal veilede for profesjonell utvikling knyttet til læreryrket. En slik forståelse er i motsetning til forståelser av veiledning som legger til grunn at profesjonelle veiledere kan veilede hvem som helst, uavhengig av yrkestilhørighet. Slike forståelser står eksempelvis sterkt i noen miljøer hvor man driver med veiledning under betegnelsen coaching (Skagen, 2013). Her argumenterer jeg altså for at profesjonalitet i veiledningsforhold i skolen forutsetter at veiledere har profesjonskompetanse og argumenterer for at lærerprofesjonskompetanse er en viktig del av veilederes profesjonskompetanse. Et slikt argument kan sies å være i overensstemmelse med bidrag fra eksempelvis Smith $(2015,2016)$ som fremhever at det er det hun kaller ekspertlærere med veilederutdanning som bør veilede nye lærere.

Basert på forskningsbidrag som omhandler læreres profesjonskompetanse (Hatlevik, 2017; Hovdenak, 2011; Ebbesen, 2007; Cochran-Smith \& Lytle, 1999) foreslår jeg delkompetanser som inngår i veilederes profesjonskompetanse. Delkompetansene innbefatter kunnskaper og ferdigheter som veiledere trenger, og som er antatt å være avgjørende for profesjonalitet i veiledningsforhold.

For det første er metodekompetanse viktig. Veiledere trenger innsikt i undervisningsmetoder og metoder for planlegging og mer generelt i strategier som er viktige i lærerrollen (Føinum, 2016; Ryeng, 2000). Samtidig trenger de et utviklet metoderepertoar knyttet til veiledning. Dette kan dreie seg og kjennskap til og ferdigheter med strategier og metoder egnet til eksempelvis å utvide veisøkers tenkning, modellere undervisning og å bruke observasjon som utgangspunkt for veiledning (Jensen, 2016; Aspfors \& Fransson, 2015; Hobson et al., 2009).

Videre trenger veiledere refleksjonskompetanse, både knyttet til refleksjon over lærerarbeidet og veilederarbeidet (Aspfors \& Fransson, 2015). Eksempelvis er det antatt å være viktig for profesjonell utvikling for lærere at de har kompetanse til kritisk å vurdere egen undervisning, elevers læring og interaksjon med kollegaer (Klemp, 2013). Veiledere trenger også slik kompetanse. I tillegg trenger de å 
kunne reflektere kritisk over egen veiledningspraksis og å kunne bidra til utvikling av veisøkers refleksjonskompetanse (Lejonberg, 2016; Bjerkholt, Ødegård, Søndenå \& Hjardemaal, 2014; Chitpin \& Evers, 2005).

Også relasjonskompetanse trekkes i forskningsbidrag frem som en viktig komponent i læreres profesjonskompetanse. Som veiledere, trenger lærere kunnskaper og ferdigheter for å bygge og opprettholde gode relasjoner til elever, kollegaer og foreldre (Skrøvset, Mausethagen, Slettbakk \& Søbstad, 2017). For veiledere er det i tillegg antatt å være avgjørende for veiledningen at man har en tillitsfull og trygg relasjon mellom veileder og veisøker (Lejonberg, Elstad, Sandvik, Solhaug \& Christophersen, i prosess; Bjørndal, 2016; Hobson et al., 2009).

Den faglige kompetansen er vurdert som en svært betydningsfull komponent i læreres profesjonskompetanse. Lærere trenger bred og dyp kunnskap om de fag de underviser i, samt om formidling av faget til de elevgrupper de jobber med (Hatlevik, 2014; Hovdenak, 2011). Flere argumenterer for at veiledere og veisøkere bør ha undervisningskompetanse i samme fag og at dette er en suksessfaktor i veiledning (Føinum, 2016; Hobson et al., 2009; T. M. Smith \& Ingersoll, 2004). Til tross for at det er delte meninger om dette blant dem som utvikler veilederopplæring (Ryeng, 2000), er det altså grunn til å tro at veilederes fagkompetanse knyttet til det undervisningsfag veiledningsforholdet foregår i sammenheng med, kan være viktig for å sikre profesjonalitet i veiledning.

Videre er læreres samfunnsorienterte kompetanse antatt å være viktig. Dette innebærer innsikt i skolens rolle i samfunnet og ferdigheter relevante for å knytte elevenes erfaringer i skolen til samfunnet for $\varnothing$ vrig (Ebbesen, 2007; Solhaug, 2003). For veiledere er det også viktig å bidra til veis $\varnothing$ keres forståelse av skolens mandat og lærerens funksjon i en overordnet sammenheng (Smith, 2016). I tillegg vektlegges en yrkesetisk kompetanse gjerne i sammenhenger hvor man beskriver læreres profesjonskompetanse (se eksempelvis Utdanningsforbundet, 2009; Ebbesen, 2007). I det følgende vil jeg gå mer utførlig inn på hva en slik kompetanse kan innebære for veiledere.

\section{Profesjonskompetanse og lederrolle}

Da det kreves en mengde kunnskaper og en bredspektret kompetanse for å være en god veileder, kan vi fastslå at veilederrollen er meget kompleks. Likevel er det vanskelig å begrunne hvorfor slik kunnskap og kompetanseheving skulle være mer utfordrende for ledere enn lærere å tilegne seg. Kanskje er det snarere tvert imot siden ledere ofte har tatt tilleggsutdanning i skoleledelse. Slik videreutdanning omhandler ofte mange av de aspekter og perspektiver som er nevnt overfor. Dette indikerer at det fins lite belegg for å hevde at det er noe med lederes kunnskaper eller erfaringer som tilsier at de ikke bør påta seg veiledningsansvar for nyutdannede. Det som kompliserer lederes veiledning av nytilsatte, må derfor bunne $\mathrm{i}$ andre momenter enn hans/hennes teoretiske og erfaringsbaserte kompetanse, for eksempel etiske sider knyttet til denne veiledningsrelasjonen.

\section{Etisk bevissthets betydning}

Etikk er gjerne forstått som en «gren av filosofien som undersøker hva som er rett og hva som er galt, og som setter normer og prinsipper for riktig handling» (Martinsen, 1991, s. 27). Fagfolk hevder at etisk bevissthet er avgjørende for veiledningsforholdet (Afdal, 2011; Kristiansen, 2008, Moberg \& Velasquez, 2004). Det er særlig to begrunnelser for hvorfor det er viktig som går igjen. Den første begrunnelsen er knyttet til tillitsforholdet som ligger til grunn for veiledningen. Å skape og opprettholde en relasjon preget av tillit og trygghet er antatt å være avgjørende for et vellykket veiledningsforhold. Flere understreker betydningen av at veisøker kan stole på at veileders lojalitet ligger hos ham/henne. Dette krever at veileder er bevisst på grenser og utfordringer relatert til egen rolle (Ulvik \& Smith, 2010; Hobson et al., 2009; Kristiansen, 2008; Clutterbuck, 2004; Kram, 1988). Den andre begrunnelsen for hvorfor etisk bevissthet er avgjørende i veiledningsforhold, er knyttet til veileders makt i veiledningsrelasjonen. Disse begrunnelsene legger til grunn at veiledningsrelasjonen er asymmetrisk ettersom veiledere ofte har mer erfaring og en høyere status enn veisøker. Veileder er dermed i en posisjon hvor mulighetene til å påvirke 
Bør ledere være veiledere for nyutdannede lærere? En problematisering basert på teori om profesjonalitet og etisk bevissthet

et annet menneske i positiv eller negativ retning kan bli store. Dette fordrer at veileder har bevissthet om egen rolleutøvelse, og påvirkning på veisøker (Bjørndal, 2016; Mathisen, 2015; Hobson et al., 2009; Kristiansen, 2008; Moberg \& Velasquez, 2004; Løgstrup, 1997; Kram, 1988).

Flere omtaler etisk bevissthet i veiledning som en forutsetning for profesjonalitet. Eksempelvis skriver Kristiansen $(2008$, s. 38) at veiledning er «basert på noe fundamentalt etisk» fordi mål, tematikk og metoder alltid må velges med utgangpunkt i hva som er det beste for veisøkeren. Afdal (2011) omtaler veiledning som en moralsk virksomhet, og hevder at etisk bevissthet er viktig for å perspektivere og utfordre eksisterende veiledningspraksis. Teori om etisk bevissthet i veiledning kan altså legges til grunn for et argument om at veilederes etiske bevissthet er en forutsetning for profesjonalitet i veiledningsforhold. Man kan imidlertid spørre seg $h v a$ veileders etiske forpliktelser overfor veis $\varnothing$ ker innebærer. Det vil si: hva er det veiledere bør være bevisste på? Basert på Cavanagh og kollegaers (1981) beskrivelser av fire etiske grunnprinsipper utleder Moberg og Velasquez (2004) syv etiske forpliktelser veiledere har overfor veisøkere (se figur 1). Selv om denne tenkningen er myntet på veiledning $i$ arbeidslivet generelt, mener jeg de kan belyse utfordringer ved det å legge veiledningsansvar til lederrollen i norsk skole.

\section{Veileders etiske forpliktelser og mulig konflikter relatert til lederrollen}

Figur 1 viser de fire moralske prinsippene (Cavanagh et al., 1981) i kombinasjon med de syv forpliktelsene utledet av Moberg og Velasquez (2004).

\begin{tabular}{|c|c|c|}
\hline $\begin{array}{l}\text { Moralske prinsipper som bør ligge } \\
\text { til grunn for handlinger på en } \\
\text { arbeidsplass: Fire kategorier } \\
\text { (Cavanagh et al. 1981) }\end{array}$ & \multicolumn{2}{|c|}{$\begin{array}{c}7 \text { etiske forpliktelser veileder har overfor veis } \varnothing \text { ker } \\
\text { (Moberg og Velasquez, 2004) }\end{array}$} \\
\hline \multirow{2}{*}{$\begin{array}{l}\text { Utilitarisme: maksimere } \\
\text { nytte og minimere byrder } \\
\text { for de ansatte. }\end{array}$} & 1. Bidra positivt & $\begin{array}{c}\text { Disponere ressurser til veisøker. Ha relevant } \\
\text { kompetanse. }\end{array}$ \\
\hline & 2. Unngå skade & $\begin{array}{c}\text { Ikke gi råd man er usikker på. Ikke ta sjanser på } \\
\text { veisøkers vegne. }\end{array}$ \\
\hline \multirow{2}{*}{$\begin{array}{c}\text { Rettighets-prinsipper: } \\
\text { Sikre de ansatte } \\
\text { grunnleggende rettigheter. }\end{array}$} & 3. Autonomi & $\begin{array}{l}\text { Bidra til at veisøker kan stå på egne ben. Ikke } \\
\text { handle på veisøkers vegne. }\end{array}$ \\
\hline & 4. Konfidensialitet & $\begin{array}{l}\text { Ikke videreformidle eller bruke kunnskap om } \\
\text { veisøker. }\end{array}$ \\
\hline \multirow{2}{*}{$\begin{array}{l}\text { Rettferdighets-prinsipper: } \\
\text { Sikre en rettferdig } \\
\text { fordeling av goder og } \\
\text { byrder blant de ansatte }\end{array}$} & 5. Rettferdighet & $\begin{array}{l}\text { Fordele byrder og goder rettferdig. Ikke } \\
\text { diskriminere når det gjelder valg av veis } \emptyset \text { ker. }\end{array}$ \\
\hline & 6. Lojalitet & $\begin{array}{l}\text { Unngå interessekonflikter hvor hensynet til } \\
\text { veisøker er i konflikt med andre hensyn }\end{array}$ \\
\hline $\begin{array}{l}\text { Omtanke-prinsipper: vise } \\
\text { omsorg for og støtte de } \\
\text { ansatte }\end{array}$ & 7. Partiskhet & $\begin{array}{l}\text { Lese omgivelsene med veisøkers beste i } \\
\text { bakhodet. Fremme veis } \emptyset \text { ker. }\end{array}$ \\
\hline
\end{tabular}

Figur 1. Illustrerer hvordan etiske forpliktelser kan utledes fra overordnede moralske prinsipper.

De første to forpliktelsene utledes med utgangspunkt i det moralske prinsippet om utilitarisme. Dette prinsippet innebærer at man alltid bør handle slik at man maksimerer nytte og minimerer byrder for andre. Ut fra dette prinsippet forplikter veileder for det første seg til å bidra positivt overfor veisøkere. Dette handler om å benytte muligheter og vise vilje til å disponere de ressursene man har tilgang til, som kunnskaper og tid, slik at de kommer veisøker til gode. Eksempelvis må veileder vurdere om han/hun har kapasitet til å fungere som veileder (Moberg \& Velasquez, 2004). Hobson et al. (2009) viser til at veisøkere som har veiledere som også er ledere, opplever veilederne sine som mer utilgjengelige. Dette kan være til hinder for godt utbytte av veiledningen. En annen utfordring som ledere kan ha, handler om å dele kunnskap som kan være nyttig for veisøker. Ledere har gjerne slik informasjon, men bør, i noen tilfeller, ikke dele den av hensyn til andre forpliktelser og krav om taushetsplikt. Veileder må også vurdere om han/hun har den veilederkompetansen som er nødvendig. Forskning indikerer at veilederutdanning er viktig i så henseende (Aspfors \& Fransson, 2015; Lejonberg, Elstad \& Christophersen, 2015; Ulvik \& Sunde, 
2013). Har man ikke formell veilederkompetanse, blir det kanskje ekstra viktig å vurdere kritisk egen evne til å veilede. I Lejonberg, Dahl, og Brovoll (akseptert) presenteres en rektors erkjennelse av at ledere ved hans skole ikke var like godt kvalifisert til å veilede som de med formell veilederkompetanse på skolen.

For det andre medfører utilitarismeprinsippet forpliktelsen til å unngå skade. Dette konkretiseres i form av føringer om ikke å gi råd man er usikker på eller ta sjanser på veisøkers vegne (Moberg \& Velasquez, 2004). De poengterer imidlertid også veileders forpliktelse til å «stå i det» og bidra til å minimere skadeomfanget dersom det viser seg at man som veileder har bidratt til noe som er problematisk for veisøker. På dette punktet kan jeg ikke se at det å være leder bidrar til spesielt store utfordringer utover dem alle veiledere vil oppleve. En kan imidlertid tenke seg at det for noen ledere kan oppleves spesielt problematisk å innrømme feil. Har man bidratt til dårlige avgjørelser, eller til at andre kom skjevt ut, kan det være ekstra utfordrende å være i lederrollen da slike feil kan skade tillitsrelasjonene $i$ et kollegium.

Det andre av de fire overordnede prinsippene omhandler rettigheter. Dette prinsippet omfatter forpliktelsen til å handle slik at de ansattes grunnleggende rettigheter sikres. Fra dette prinsippet utledes to forpliktelser veiledere har overfor veisøkere: (a) å sikre autonomi og (b) konfidensialitet. Å sikre autonomi innebærer å utvikle veisøkers evne til å stå på egne ben ved å ta egne avgjørelser. Eksempelvis er det viktig at veiledere ikke har egne interesser i å styre veisøkers valg, og at de kan bidra til at veisøker får all nødvendig informasjon når de skal fatte en beslutning (Moberg \& Velasquez, 2004). Her kan veiledere med lederansvar muligens stå overfor ekstra utfordringer. For det første deltar ledere på flere arenaer hvor beslutninger tas og har dermed flere anledninger til å handle på veisøkers vegne. For det andre kan det være at leder opplever situasjoner hvor innsikt som hadde vært nyttig for en veisøkers avgjørelse, må holdes tilbake på grunn av andre forpliktelser leder har. Et tredje eksempel er at ledere har ansvar for å rekruttere og beholde de beste lærere for å sørge for skolens kvalitet og renomme. Slike hensyn kan komme i konflikt med forpliktelsen til ikke å styre veisøkers valg eksempelvis dersom en veisøker vurderer å skifte arbeidsplass.

Videre utledes også en forpliktelse til konfidensialitet fra rettighets-prinsippet. Ettersom veiledningsrelasjonen bygger på tillit, er det avgjørende at veisøker kan stole på at innsikt veileder får om veis $\varnothing$ ker, ikke brukes mot veis $\varnothing$ ker i noen sammenheng. Veileder må derfor ikke videreformidle kunnskap om veisøker, og heller ikke handle på bakgrunn av innsikt i veisøkers situasjon. Veileder må altså være bevisst på at innsikt han/hun har om veisøker, ikke må føre til noen form for ulempe for veisøker. Bare dersom veisøker har gitt sitt samtykke til at veileder handler på veis økers vegne for å sikre veisøkers interesser, bør veileder gjøre det (Moberg \& Velasquez, 2004). Konfidensialitetsforpliktelsen viser hvordan lederansvar problematiserer veilederrollen. Helt konkret kan veileder via veis $\varnothing$ ker få innsikt i problemer i organisasjonen som det bør tas tak i. Å gjøre det uten at veisøker som kilde får problemer, kan være vanskelig eller umulig. Og hvordan skal leder unngå å bruke innsikt om veisøker dersom han/hun har ansvar for oppgaver som eksempelvis forlengelse av midlertidige ansettelser, individuelle lønnstillegg eller fordeling av ansvar og oppgaver i et lærerkollegium?

Det tredje prinsippet som bør ligge til grunn for handlinger på en arbeidsplass, er rettferdighet. I skolesammenheng innebærer det å handle slik at fordeling av goder og byrder blant lærerne blir rimelig lik. Fra prinsippet utledes at veiledere også har en forpliktelse til å fordele goder og byrder rettferdig mellom sine veisøkere. Dette er krevende uavhengig av om veileder også har en lederrolle. Veiledere kan oppleve å ha en bedre relasjon til noen veisøkere enn andre. Det er da veileders forpliktelse at slike preferanser ikke må bidra til skjevfordeling, eller urettferdighet, eksempelvis i forbindelse med hvordan man fordeler tid og ressurser mellom veisøkere. Det kan være ekstra utfordrende for ledere å opprettholde en slik rettferdig ressursfordeling når man er veileder for noen ansatte, og ikke andre. Også når man skal sette sammen veiledningsrelasjoner er det viktig å være bevisst på å gjøre rettferdige valg. Ledere peker gjerne ut hvem som skal veilede hvilke veisøkere. At ledere velger seg selv til noen veisøkere og ikke andre, kan komme i konflikt med en slik rettferdighets-forpliktelse. Også overfor andre veiledere og veisøkere kan det være viktig å tydeliggjøre hvilke kriterier som ligger til grunn for sammenkopling av veiledere og veisøkere (Moberg \& Velasquez, 2004). 
Bør ledere være veiledere for nyutdannede lærere? En problematisering basert på teori om profesjonalitet og etisk bevissthet

Med utgangpunkt i rettferdighetsprinsippet utledes også en forpliktelse til lojalitet. Dette dreier seg først og fremst om å unngå interessekonflikter hvor hensynet til veisøker er i konflikt med andre hensyn. Det er lojaliteten til veisøker som til enhver tid må veie tyngst for veiledere (Moberg \& Velasquez, 2004). En slik forpliktelse kan by på utfordringer for en leder. Eksempelvis kan lojaliteten overfor veis $\emptyset$ ker komme i konflikt med lojaliteten overfor lærerkollegiet for $\varnothing$ vrig. Dersom lederen fungerer som veileder og «oppdager» gjennom veiledningen at veisøker har store utfordringer med å fungere i lærerrollen, hvordan skal denne lederen balansere hensynet til elevenes behov for en dyktig lærer opp mot forpliktelsen han/hun har som veileder, nemlig å støtte veisøker og tro på at denne kan utvikle seg positivt? Eller motsatt; dersom en svært dyktig veisøker vurderer et annet jobbtilbud som kan være utviklende for vedkommende, hvordan balanserer da en leder hensynet til veis $\varnothing$ ker med lojaliteten overfor elevene og kollegiet ved skolen?

Det siste prinsippet som nevnes i figur 1, er omtankeprinsippet. Fra dette prinsippet utledes forpliktelsen til partiskhet. I dette ligger å fremme veisøker og det som i situasjonen er best for vedkommende. Dette sammenliknes med hvordan gode foreldre hjelper egne barn til å utnytte sjanser som byr seg. Eksempelvis kan det dreie seg om å oppmuntre til eller legge til rette for at veisøker får et engasjement, eller å gripe andre muligheter, de kan vokse på (Moberg \& Velasquez, 2004). Ettersom ledere har personalansvar også for andre enn dem de er veiledere for, kan det by på problemer å fronte veisøkere på denne måten. For en leder i veilederrollen vil hensynet til og forpliktelser overfor andre i organisasjonen altså kunne komme i konflikt med hensynet til veisøker.

En utforskning av hvilke forpliktelser som ligger til veilederrollen, tydeliggjør hvordan lederansvar kan komplisere veilederrollen. Som nevnt beskriver Afdal (2011) at en etisk bevissthet må ligge til grunn for veiledningsforhold fordi et slikt fokus utfordrer veiledningspraksis. Gjennomgangen av etiske forpliktelser over tydeliggjør hvordan vurderinger som tar utgangspunkt i moralske prinsipper kan utfordre tenkningen om veiledning og bidra til større bevissthet knyttet til ut $\varnothing$ velse av veilederrollen.

\section{Konklusjoner}

Basert på den teorien og de argumenter som her er presentert, argumenterer jeg for etisk bevissthet som en nødvendig, men ikke tilstrekkelig betingelse for profesjonskompetanse og dermed for profesjonalitet i veiledningsforhold. Denne sammenhengen skisseres i modellen under.
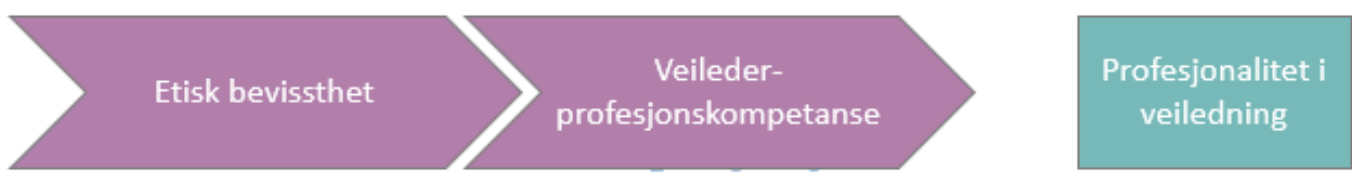

Figur 2. Skisserer hvordan etisk bevissthet inngår i, og er en forutsetning for veilederes profesjonskompetanse, som igjen er en forutsetning for profesjonalitet $\mathrm{i}$ veiledning.

Den presenterte teori og min argumentasjon viser at det ikke primært er mangel på kunnskap eller kompetanse som skaper utfordringer relatert til å legge veiledningsansvaret for nyutdannede til ledere. Utfordringene ligger derimot i situasjoner og forhold hvor forpliktelsene overfor veis $\varnothing$ ker kan komme i konflikt med andre forpliktelser og forventninger knyttet til lederrollen. Lederes forpliktelser overfor andre arbeidsoppgaver og aktører i skolen enn veisøker utfordrer altså tillitsrelasjonen som må ligge til grunn for forholdet mellom en veileder og en veisøker. Spesielt utfordres relasjonen til andre ansatte som ledere har forpliktelser overfor. Asymmetrien, lederes makt og forpliktelser til andre aktører utenfor veiledningsforholdet kompliserer, som vist, veiledningsforholdet.

Vil det si at konklusjonen er at ledere ikke kan være veiledere for nyutdannede lærere? Svaret på det er ikke nødvendigvis et entydig nei. Ledere har en viktig rolle når det gjelder å legge til rette for veiledning 
og å sikre at nyutdannede får veiledning (Nettverket, 2018b; Rambøll, 2016). Ledere har også personalansvar, noe som innebærer at de følger opp og veileder alle lærere i ulike sammenhenger (Brandmo \& Aas, 2017; Lejonberg et al., 2017; Utdanningsdirektoratet, 2015). Men utfordringene som følger med forpliktelsene knyttet til henholdsvis lederrollen og veilederrollen, indikerer at veis $\varnothing$ kere trolig vil ha mer utbytte av å ha en veileder som ikke er leder $i$ tillegg. Jeg hevder altså at nyutdannede lærere er mer tjent med å ha en kollega uten lederansvar som veileder. Et slikt veiledningsforhold vil antakelig $\emptyset$ ke potensialet for veisøkers profesjonelle utvikling i veiledning. $\emptyset$ nsker man at dette vekstpotensialet realiseres fordrer det at skoleeiere bevisst satser ressurser på veiledning med veiledningskvalifiserte lærere som veiledere for de nye.

Veiledning er vanskelig for alle veiledere. Skal ledere være veiledere, står de overfor ekstra store utfordringer og vanskelige avveininger. Dette krever en ekstra bevissthet i tillegg til at de er ekstra tydelige overfor veisøker på hvilke forpliktelser de har og på hvilke vurderinger som er i spill. Imidlertid er det vanskelig å se hvordan en slik bevissthet og tydelig kommunikasjon kan løse alle slike utfordringer som dem som er presentert her. Forpliktelsene en veileder har overfor veisøker er vanskelige å forene med andre forpliktelser knyttet til lederrollen.

\section{Litteratur}

Afdal, G. (2011). Veiledning som moralsk virksomhet. I T. J. Karlsen (Red.), Veiledning under nye vilkår (s. 124-139). Oslo: Gyldendal akademisk.

Arnesen, C. Å. \& Aamodt, P. O. (2010). Fra lærerutdanning til skole: en undersøkelse blant nyutdannede allmennlærere i 2009 (NIFU-rapport 2010:32). Hentet fra https://brage.bibsys.no/xmlui/handle/11250/279401

Aspfors, J. \& Fransson, G. (2015). Research on mentor education for mentors of newly qualified teachers: A qualitative meta-synthesis. Teaching and Teacher Education, 48, 75-86.

Bjerkholt, E., Ødegård, E., Søndenå, K. \& Hjardemaal, F. R. (2014). Hvordan kan veiledningssamtaler åpne for kritisk tenkning? Uniped, 37(4), 19-31.

Bjørndal, C. R. P. (2016). Konstruktive hjelpesamtaler: mestringsfremmende perspektiver og redskaper $i$ veiledning, rådgivning, mentoring og coaching. Oslo: Gyldendal.

Brandmo, C. \& Aas, M. (2017). Med skråblikk på ledelsesmodeller: "Instructional" og "transformational" ledelse i norsk kontekst. I M. Aas \& J. M. Paulsen (Red.), Ledelse i fremtidens skole. Bergen: Fagbokforlaget.

Caspersen, J. \& Raaen F. D. (2014). Novice teachers and how they cope. Teachers and Teaching, 20(2), 189-211.

Cavanagh, G. F., Moberg, D. J. \& Velasquez, M. (1981). The ethics of organizational politics. The Academy of management review, 6(3), 363-374.

Chitpin, S. \& Evers, C. W. (2005). Teacher professional development as knowledge building: a Popperian analysis. Teachers and Teaching, 11(4), 419-433.

Clutterbuck, D. (2004). Everyone needs a mentor: Fostering talent in your organisation (4. utg.). London: Chartered Institute of Personnel and Development.

Cochran-Smith, M. \& Lytle, S. L. (1999). Relationships of knowledge and practice: Teacher learning in communities. Review of research in education 24(1), 249-305.

Dahl, A. K. \& Scheie, J. (kommer). How can teacher education programs prepare future teachers to deal with their emotions rather than becoming overwhelmed by them?

Ebbesen, A. G. (2007). Mirakelkur eller dannelsesprosjekt? Pedagogikk i praktisk-pedagogisk utdanning. I R. Mikkelsen \& H. Fladmoe (Red.), Lektor-adjunkt-lærer: artikler for studiet i praktisk-pedagogisk utdanning (s. 25-51). Oslo: Universitetsforlaget.

Evans, L. (2008). Professionalism, Professionality and the development of education professionals. British journal of educational studies, 56(1), 20-38. 
Bør ledere være veiledere for nyutdannede lærere? En problematisering basert på teori om profesjonalitet og etisk bevissthet

Føinum, M. (2016). Når skolens behov blir viktigere enn formell kompetanse: Hvordan veilede nyutdannede lærere til å undervise i skolefag de ikke har? Acta Didactica Norge, 10(2), 290-310.

Harrison, J., Dymoke, S. \& Pell, T. (2006). Mentoring beginning teachers in secondary schools: An analysis of practice. Teaching and Teacher Education, 22(8), 1055-1067.

Hatlevik, I. K. R. (2014). Meningsfulle sammenhenger: En studie av sammenhenger mellom læring på ulike arenaer og utvikling av ulike aspekter ved profesjonell kompetanse hos studenter i sykepleier-, lærer-og sosialarbeiderutdanningene (Doktoravhandling). Høgskolen i Oslo og Akershus.

Hatlevik, I. K. R. (2017). The impact of prospective teachers' perceived competence on subsequent perceptions as schoolteachers. Teachers and Teaching, 23(7), 810-828.

Hobson, A. J., Ashby, P., Malderez, A. \& Tomlinson, P. D. (2009). Mentoring beginning teachers: What we know and what we don't. Teaching and Teacher Education, 25(1), 207-216.

Hobson, A. J. \& Malderez, A. (2013). Judgementoring and other threats to realizing the potential of school-based mentoring in teacher education. International Journal of Mentoring and Coaching in Education, 2(2), 89-108.

Hobson, A. J. \& McIntyre, J. (2013). Teacher fabrication as an impediment to professional learning and development: the external mentor antidote. Oxford Review of Education, 39(3), 345-365.

Hovdenak, S. S. (2011). Utdanningssosiologi: fra teori til praksis i skolen. Trondheim: Tapir akademisk forlag.

Illeris, K. (2011). The fundamentals of workplace learning: understanding how people learn in working life. London: Routledge.

Jensen, A. R. (2016). Veiledningsritualet: en dialektisk studie av formaliserte veiledningssamtaler $i$ lærerutdanningens praksisperiode (Doktoravhandling). Universitetet i Agder, Kristiansand.

Klemp, T. (2013). Refleksjon - hva er det, og hvilken betydning har den i utdanning til profesjonell lærerpraksis? Uniped, 36(01), 42-58.

Kram, K. E. (1988). Mentoring at work: Developmental relationships in organizational life. Maryland, USA: University Press of America.

Kristiansen, A. (2008). Hva skiller en veiledningssamtale fra andre samtaler? Veiledningssamtalens egenart og etiske utfordringer. I D. G. Aasland, H. I. Sævareid, S. B. Eide, H. H. Grelland \& A. Kristiansen (Red.), Til den andres beste. En bok om veiledningens etikk. Oslo: Gyldendal.

Lejonberg, E. (2014). Nyutdannede lærere: Mentors rolle ved ansettelsesvurdering. Bedre skole 11(3), 31-35.

Lejonberg, E. (2016). Hva kan bidra til god veiledning? En problematisering basert på veilederes og veisøkeres perspektiver på veiledning av begynnende lærere (Doktoravhandling), Universitetet i Oslo.

Lejonberg, E., Dahl, A. K. \& Brovoll, S. P. (akseptert). Nye forventninger til veilederrollen: veileder som leder av utviklingsprosjekter i skolen. I K. Helstad \& S. Mausethagen (Red.), Nye lederroller i skolen. Oslo: Universitetsforlaget.

Lejonberg, E. \& Elstad, E. (2014). Bruk av profesjonsbegrepet i kampen om utdanningspolitikkens innhold. I E. Elstad \& K. Helstad (Red.), Profesjonsutvikling i skolen. Oslo: Universitetsforlaget.

Lejonberg, E., Elstad, E. \& Christophersen, K.-A. (2015). Mentor education: challenging mentors' beliefs about mentoring. International Journal of Mentoring and Coaching in Education, 4(2), 142-158.

Lejonberg, E., Elstad, E. \& Christophersen, K. A. (2017). Teaching evaluation: antecedents of teachers' perceived usefulness of follow-up sessions and perceived stress related to the evaluation process. Teachers and Teaching, 24(3), 281-296.

Lejonberg, E., Elstad, E., Sandvik, L., Solhaug, T. \& Christophersen, K. A. (submitted). Developmental Relationships in Schools: How School Mentors' Priorities Matter to Pre-service teachers. Mentoring \& Tutoring: Partnership in Learning. 
Long, J. (1997). The dark side of mentoring. The Australian Educational Researcher, 24(2), 115-133.

Lortie, D. C. (1975). School teacher: A sociological inquiry. Chicago: University of Chicago Press.

Løgstrup, K. E. (1997). On trust. I H. Jodalen \& A. J. Vetlesen (Red.), Closeness. An ethics. Oslo: Universitetsforlaget.

Martinsen, V. (1991). Filosofi: en innføring. Oslo: Kontekst.

Mathisen, P. (2015). Mentor: mentoring i teori og praksis (2. utg.). Bergen: Fagbokforlaget.

Mausethagen, S. \& Granlund, L. (2012). Contested discourses of teacher professionalism: current tensions between education policy and teachers' union. Journal of Education Policy, 27(6), 815-833.

Moberg, D. J. \& Velasquez, M. (2004). The Ethics of Mentoring. Business Ethics Quarterly, 14(1), 95-122.

Molander, A. \& Terum, L. I. (2008). Profesjonsstudier - en introduksjon. I A. Molander \& L. I. Terum (Red.), Profesjonsstudier (s. 13-27). Oslo: Universitetsforlaget.

Nettverket for veiledning av nyutdannede lærere. (2018a). Veilederkompetanse. Hentet fra https://www.nyutdannede.no/praktisk-gjennomfoering/tips-til-veiledere/veilederkompetanse/

Nettverket for veiledning av nyutdannede lærere. (2018b). Arbeidsgivers ansvar. Hentet fra https://www.nyutdannede.no/praktisk-gjennomfoering/tips-til-arbeidsgiver/arbeidsgivers-ansvar/

Rambø|l. (2014). Veiledningsordning for nytilsatte nyutdannede lærere og barnehagelærere. Resultater fra kartleggingen 2014. Hentet fra http://static.websys.no/files/sites/veiledningnyutdannede.hit.no/contentfiles/201404/2014 barnehager veiledningsordningen kartlegging.pdf

Rambøll. (2015). Evaluering av veiledningsordningen for nyutdannede pedagoger i barnehage og skole. Hentet fra http://www.udir.no/globalassets/filer/tall-og-forskning/forskningsrapporter/nydelrapport-evaluering-av-veiledningsordningen-for-nyutdannede-pedagoger-i-barnehage-og-skolevedlegg-inkl.pdf

Rambøll. (2016). Veiledning av nyutdannede barnehagelærere og lærere: en evaluering av veiledningsordningen og veilederutdanningen. Hentet fra https://www.udir.no/globalassets/filer/tall-og-forskning/rapporter/2016/evaluering-avveiledningsordningen-sluttrapport.pdf

Ryeng, S. (2000). Fagdidaktisk kollegaveiledning i skolen: Faglighet - mulighet eller hindring? I K. Skagen (Red.), Kunnskap og handling i pedagogisk veiledning (s. 163-174). Bergen: Fagbokforlaget.

Skagen, K. (2013). I veiledningens landskap: innføring i veiledning og rådgivning. Oslo: Cappelen Damm akademisk.

Skrøvset, S., Mausethagen, S. \& Slettbakk, Å. (2017). Lærerens relasjonsarbeid: perspektiver, verktøy og caser. Oslo: Cappelen Damm akademisk.

Smith, K. (2015). Mentoring: A profession within a profession. I H. H. Tillema, G. J. v. d. Westhuizen \& K. Smith (Red.), Mentoring for learning (s. 283-298). Rotterdam: Sense Publishers.

Smith, K. (2016). Mentorer - skolebaserte lærerutdannere: ansvar og krav. I A.-L. Østern \& G. Engvik (Red.), Veiledningspraksiser i bevegelse. Skole, utdanning og kulturliv (s. 197-207). Oslo: Fagbokforlaget.

Smith, K. (2018). Mentorrollen - norske og internasjonale stemmer. I K. Smith \& M. Ulvik (Red.), Veiledning av nye lærere. Nasjonale og internasjonale perspektiver (s. 23-40). Oslo: Universitetsforlaget.

Smith, K., Ulvik, M. \& Helleve, I. (2013). Førstereisen: Iærdom hentet fra nye læreres fortellinger. Oslo: Gyldendal akademisk.

Smith, T. M. \& Ingersoll, R. M. (2004). What are the effects of induction and mentoring on beginning teacher turnover? American educational research journal, 41(3), 681-714.

Solhaug, T. (2003). Utdanning til demokratisk medborgerskap (Doktoravhandling). Universitetet i Oslo. 
Bør ledere være veiledere for nyutdannede lærere? En problematisering basert på teori om profesjonalitet og etisk bevissthet

Sorensen, R. (2006). Vagueness. I Stanford Encyclopedia of Philosophy website. Hentet fra http://plato.stanford.edu/entries/vagueness/

Stålsett, U. (2006). Veiledning i en lærende organisasjon. Oslo: Universitetsforlaget.

Svensson, L. G. (2006). New professionalism, trust and competence: Some conceptual remarks and empirical data. Current sociology, 54(4), 579-593.

Troye, S. V. (1994). Teori- og forskningsevaluering. Et kritisk realistisk perspektiv. Oslo: TANO.

Ulvik, M. \& Smith, K. (2010). Veiledning av nye lærere: nasjonale og internasjonale perspektiver. Oslo: Universitetsforlaget.

Ulvik, M. \& Smith, K. (2011). En profesjon innenfor profesjonen. Bedre skole, (4), 82-87.

Ulvik, M. \& Sunde, E. (2013). The impact of mentor education: does mentor education matter? Professional Development in Education, 39(5), 754-770.

Utdanningsdirektoratet. (2015). Ledelse i skolen. Krav og forventninger til en rektor. Hentet fra https://www.udir.no/globalassets/filer/skoleutvikling/rektorutdanning/skoleledere bokmaal.pdf

Utdanningsdirektoratet. (2017). Veiledning av nyutdannede. Hentet fra https://www.udir.no/kvalitetog-kompetanse/veiledning-av-nyutdannede/

Utdanningsetaten. (2018). Utvikle deg som lærer i Osloskolen. Hentet fra https://jobb.osloskolen.no/karrieremuligheter/laerer/

Utdanningsforbundet. (2009). En ansvarlig og offensiv profesjon. Hentet fra https://www.utdanningsforbundet.no/PageFiles/70412/ProfesjonPlakat\%20UDF.pdf

Varah, L. J., Theune, W. S. \& Parker, L. (1986). Beginning teachers: Sink or swim? Journal of teacher education, 37(1), 30-34.

Varzi, A. C. (2001). Vagueness, Logic, and Ontology. The Dialogue. Yearbooks for Philosophical Hermeneutics, (1), 135-154.

Wittek, L. \& Kvernbekk, T. (2011). On The Problems of Asking for a Definition of Quality in Education Scandinavian Journal of Educational Research, 55(6), 671-684. 